\title{
PENGARUH MODEL PEMBELAJARAN KOOPERATIF \\ TIPE TEAM GAMES TOURNAMENT (TGT) TERHADAP HASIL BELAJAR MATEMATIKA SISWA SD
}

\author{
Ujiati Cahyaningsih ${ }^{1)}$ \\ ujiati.cahyaningsih31@gmail.com \\ Universitas Majalengka
}

Pada dasarnya permasalahan yang terjadi dikarenakan tidak semua materi pelajaran matematika mudah dipahami oleh siswa dan mudah disampaikan oleh guru, sehingga seringkali kesulitan muncul pada saat mempelajari materi - materi tertentu. Penelitian ini bertujuan untuk mengetahui pengaruh model pembelajaran kooperatif tipe TGT terhadap hasil belajar matematika baik aspek kognitif, afektif maupun psikomotor. Metode yang digunakan dalam penelitian ini yaitu dengan eksperimen.Teknik pengambilan sampel dilakukan dengan cluster random sampling. Teknik pengambilan datanya untuk aspek kognitif dilakukan dengan soal evaluasi, untuk aspek afektif berupa angket, dan untuk aspek psikomotor dilakukan dengan lembar unjuk kerja. Materi pelajaran yang digunakan dalam penelitian ini yaitu materi geometri. Penelitian ini dianalisis menggunakan uji t. Hasil yang diperoleh yaitu (1) Aspek kognitif dari hasil uji $t$ diperoleh $t_{\text {hitung }}>t_{\text {tabel }}$ atau 2,073>1,980 melalui SPSS 16,0 didapatkan pula nilai signifikasi sebesar 0,044. (2) Aspek afektif dari hasil uji t diperoleh $t_{\text {hitung }}<t_{\text {tabel }}$ atau 1,85<1,980 melalui SPSS 16,0 didapatkan pula signifikasi 0,118. (3) Aspek psikomotor dari hasil uji $\mathrm{t}$ diperoleh $\mathrm{t}_{\text {hitung }}>\mathrm{t}_{\text {tabel }}$ atau 4,226>1,980 melalui SPSS 16,0 didapatkan pula nilai signifikasi sebesar 0,000 . Jadi, ada pengaruh model pembelajaran kooperatif tipe TGT terhadap hasil belajar matematika aspek kognitif dan psikomotor pada siswa dan tidak ada pengaruh model pembelajaran kooperatif tipe TGT terhadap hasil belajar matematika aspek afektif pada siswa.

Kata Kunci: Penelitian eksperimen, model pembelajaran kooperatif tipe TGT, hasil belajar

\footnotetext{
${ }^{1}$ Penulis adalah dosen tetap Prodi PGSD Fakultas Pendidikan Dasar dan Menengah Universitas Majalengka
} 


\section{PENDAHULUAN}

Pendidikan memiliki peran penting dalam kemajuan dan perkembangan bangsa. Para generasi penerus bangsa hendaknya menyadari akan tanggung jawab yang ada dibenak mereka dalam rangka meningkatkan kualitas sumber daya manusia yang ada. Pada kenyataannya proses pembelajaran matematika tidak selamanya berjalan efektif. Hal ini dikarenakan tidak semua materi pelajaran matematika mudah dipahami oleh siswa dan mudah disampaikan oleh guru, sehingga seringkali kesulitan muncul pada saat mempelajari materi - materi tertentu.

Pada dasarnya pelajaran matematika di sekolah dasar menanamkan konsep - konsep dasar matematika sederhana yang menjadi pengetahuan awal sebelum siswa belajar di tingkat yang lebih tinggi. Dengan demikian guru sebagai penyampai pengetahuan harus yakin dan mampu mengajarkan materi dasar dengan baik dan benar. Hal ini yang juga penting dilakukan oleh guru adalah bagaimana menciptakan pembelajaran matematika yang menyenangkan sehingga mampu memunculkan kecintaan dan kesukaan anak pada pelajaran ini.

Salah satu hal yang dapat dilakukan oleh guru untuk mencapai tujuan di atas adalah dengan melakukan variasi pembelajaran. Jika selama ini guru lebih banyak menggunakan pembelajaran langsung, maka ada baiknya guru mencoba menerapkan metode atau model pembelajaran lainnya.

Atas permasalahan tersebut, diadakan penelitian bertujuan untuk mengetahui pengaruh model pembelajaran kooperatif tipe Team Games Turnamen (TGT) terhadap hasil belajar matematika siswa SD dalam bentuk penelitian eksperimen.

Berdasarkan latar belakang masalah di atas, maka dirumuskan masalah yaitu: apakah ada pengaruh model pembelajaran kooperatif tipe Team Games Turnamen
(TGT) terhadap hasil belajar matematika aspek kognitif, afektif, dan psikomotor siswa SD. Tujuan penelitian ini yaitu untuk mengetahui pengaruh model pembelajaran kooperatif tipe Team Games Turnamen (TGT) terhadap hasil belajar matematika aspek kognitif, afektif, dan psikomotor siswa SD.

Model pembelajaran ini merupakan salah satu model pembelajaran kooperatif yang menggunakan tim kerja dan turnamen mingguan yang berupa permainan akademik yang dimainkan oleh siswa dengan anggota tim lain untuk menyumbangkan poin bagi skor timnya tanpa harus ada perbedaan status. Peran siswa disini sebagai tutor sebaya dan mengandung unsur permainan (Slavin, 2011: 13).

Model pembelajaran ini pemindahan pengetahuan secara langsung oleh guru kepada peserta didik secara langsung, misalnya melalui ceramah, demonstrasi, dan tanya jawab (Roy Killen dalam Kemendiknas, 2010: 23). Model pembelajaran langsung memiliki karakteristik sebagai berikut: a) Transformasi dan keterampilan secara langsung. b) Pembelajaran berorientasi pada pembelajaran tertentu. c) Materi pembelajaran yang terstruktur. d) Lingkungan belajar yang telah tersruktur. e) Distruktur oleh guru. (Departemen Pendidikan Nasional, 2010:24 )

Hasil belajar adalah hasil yang diperoleh oleh siswa setelah melakukan proses pembelajaran, yang mencakup nilai kognitif yang bisa dilihat dari hasil evaluasi pekerjaan siswa, afektif (angket yang dikhususkan pada karakter bangsa berupa tanggungjawab) dan psikomotor (keterampilan). Siswa nantinya diharapkan dapat meningkatkan hasil belajar siswa khususnya mata pelajaran Matematika.

\section{METODE PENELITIAN}

Metode penelitian memiliki peranan di dalam proses penelitian yang 
akan dilaksanakan. Metode yang digunakan dalam penelitian ini adalah metode eksperimen. Menurut Sugiyono (2010:107) metode penelitian eksperimen diartikan sebagai metode penelitian yang digunakan untuk mencari pengaruh perlakuan tertentu terhadap yang lain dalam kondisi yang terkendalikan.

Penelitian ini dilakukan di kelas IV SD Negeri Danaraja dengan jumlah populasi 73 siswa. Teknik pengambilan sampel menggunakan cluster random sampling. Menurut Sukardi (2011: 61) Cluster Random Sampling artinya memilih sampel bukan didasarkan pada individual, tetapi lebih didasarkan pada kelompok, daerah, atau kelompok subjek yang secara alami berkumpul bersama. Kelompok dalam penelitian ini adalah siswa kelas IVA dan IVB SD Negeri Danaraja. Semua siswa kelas IV adalah homogen maka pengambilan sampelnya dipilih menggunakan teknik pengambilan sampel Acak/Random Sederhana (Random Sampling) untuk menentukan kelas eksperimen dan kelas kontrol. Sampel dalam penelitian ini adalah kelas IV B sebanyak 41 siswa menjadi kelas eksperimen dan kelas IV A sebanyak 32 siswa menjadi kelas kontrol. Instrumen penelitian menggunakan teknik tes evaluasi untuk mengetahui hasil belajar aspek kogitif, angket untuk aspek afektif, dan unjuk kerja untuk hasil belajar matematika aspek psikomotor.
Metode analisis data menggunakan uji prasyarat yaitu uji normalitas data, uji homogenitas data, dan uji hipotesis. Uji perbedaan dua rata-rata dengan rumus: $t_{\text {hitung }}=\frac{\overline{x_{1}}-\overline{x_{2}}}{S \sqrt{\frac{1}{n x_{1}}+\frac{1}{n x_{2}}}}$ untuk $n x_{1}$ (jum lah siswa kelas eksperimen); $n x_{2}$ (jumlah siswa kelas kontrol); S (Standar deviasi gabungan). Standar deviasi gabungan dapat dicari dengan menggunakan rumus $s=$ $\sqrt{\frac{\left(n_{1}-1\right) s_{1}{ }^{2}+\left(n_{2}-1\right) s_{2}^{2}}{n_{1}+n_{2}-2}}$.

\section{HASIL PENELITIAN DAN PEMBAHASAN}

Rata-rata nilai kognitif kelas eksperimen adalah 68,57. Sementara untuk rata-rata nilai kognitif kelas kontrol adalah 63,16. Dalam perhitungan menggunakan SPSS juga didapatkan signifikansi sebesar 0,044 yang artinya signifikansi $<0,05$ berarti Ho ditolak dan $\mathrm{Ha}$ di terima. Jadi, terdapat pengaruh model pembelajaran kooperatif tipe TGT terhadap hasil belajar matematika pada aspek kognitif di kelas IV SD Negeri Danaraja. Dari data tersebut dapat diketahui bahwa rata-rata nilai kelompok eksperimen terjadi peningkatan setelah mendapatkan perlakuan. Lebih jelasnya dapat dilihat di Tabel 1 .

Tabel 1. Hasil Perhitungan Hasil Belajar Matematika Aspek Kognitif

\begin{tabular}{|c|c|}
\hline Uji Normalitas & $\begin{array}{c}\text { Kelas Kontrol }=5,184<12,59 \\
\text { Kelas Eksperimen }=1,718<11,070\end{array}$ \\
\hline Uji Homogenitas & $1,36<1,76$ \\
\hline Uji t & $2,073>1,980$ \\
\hline
\end{tabular}

Penelitian ini menggunakan nilai Ujian Tengah Semester (UTS) sebagai nilai pre tes. Hal ini karena dengan UTS siswa telah diuji kemampuannya dengan soal yang sama secara bersama-sama. Pada mendapatkan perlakuan (treatment) menggunakan model pembelajaran kooperatif tipe TGT, sedangkan pada kelas kontrol menggunakan model pembelajaran langsung. Ada pengaruh pada model 
pembelajaran kooperatif tipe TGT terhadap hasil belajar aspek kognitif siswa, disebabkan karena perbedaan perlakuan yang diberikan kepada kedua kelas tersebut. Pada proses pembelajaran kelas eksperimen siswa mendapat perlakuan menggunakan kooperatif tipe TGT akan mendorong siswa untuk mampu mengembangkan sendiri fakta dan konsep yang berkaitan dengan materi yang akan dipelajari.

Rata-rata hasil belajar aspek afektif yaitu untuk kelompok kontrol adalah 35,21 sedangkan kelompok eksperimen adalah 37,21. Dari perhitungan menggunakan SPSS juga diperoleh nilai signifikansi sebesar 0,118 yang artinya signifikansi > 0,05 atau $0,118>0,05$ hal ini berarti berarti Ho di terima dan Ha ditolak. Jadi, tidak terdapat pengaruh model pembelajaran kooperatif tipe TGT terhadap hasil belajar matematika pada aspek afektif di kelas IV SD Negeri Danaraja. Kelompok eksperimen lebih besar dari pada kelompok kontrol setelah mendapatkan perlakuan. Lebih jelasnya dapat dilihat di Tabel2.

Tabel 2. Hasil Perhitungan Hasil Belajar Matematika Aspek Afektif

\begin{tabular}{|c|c|}
\hline Uji Normalitas & $\begin{array}{l}\text { Kelas Kontrol }=2,745<12,592 \\
\text { Kelas Eksperimen }=0,716<11,070\end{array}$ \\
\hline Uji Homogenitas & $1,278<1,74$ \\
\hline Uji t & $1,85<1,980$ \\
\hline
\end{tabular}

Tidak adanya pengaruh pada model pembelajaran kooperatif tipe TGT terhadap hasil belajar aspek afektif siswa, disebabkan karena tidak adanya pemantauan secara penuh terhadap kegiatan siswa di luar mata pelajaran. Kegiatan di luar kelas yang tidak terpantau memungkinkan siswa untuk bertindak sesuai dengan keinginannya dan kurang memperhatikan sikap sehari-hari sebagai contoh saat mengerjakan lembar angket hanya beberapa siswa yang mengerjakan dengan serius sedangkan yang lain sibuk bermain sendiri atau mengobrol dengan teman-temannya. Selain hal tersebut, waktu pelaksanaan penelitian cukup singkat sedangkan dalam pembentukkan sikap seorang anak diperlukan waktu yang cukup lama.

Hasil penilaian dalam aspek psikomotor dengan menggunakan tes unjuk kerja. Berdasarkan perhitungan yang telah dilakukan, dapat diketahui bahwa rata-rata hasil angket kelas control adalah 9,93 sedangkan kelas eksperimen adalah 11,40. Dari perhitungan menggunakan SPSS juga diperoleh nilai signifikansi sebesar 0,000 hal ini berarti signifikasi< 0,05 atau $0,000<0,05$ yang berarti $\mathrm{Ho}$ ditolak dan $\mathrm{Ha}$ diterima. Jadi, terdapat pengaruh model pembelajaran kooperatif tipe TGT terhadap hasil belajar matematika pada aspek psikomotor di kelas IV SD Negeri Danaraja. Lebih jelasnya dapat dilihat di Tabel3.

Tabel 3. Hasil Perhitungan Hasil Belajar Matematika Aspek Psikomotor

\begin{tabular}{|c|c|}
\hline Uji Normalitas & $\begin{array}{l}\text { Kelas Kontrol }=1,959<11,070 \\
\text { Kelas Eksperimen }=6,228<11,070\end{array}$ \\
\hline Uji Homogenitas & $1,264<1,76$ \\
\hline Uji t & $4,226>1,980$ \\
\hline
\end{tabular}


Ada pengaruh pada model pembelajaran kooperatif tipe TGT terhadap hasil belajar aspek psikomotor siswa, disebabkan karena siswa mengalami sendiri secara langsung proses pembuatan alat peraga yaitu pembuatan gambar jajargenjang dan segitiga yang kemudian dipotong dengan bentuk jajargenjang dan segitiga yang sesuai ukuran yang telah ditentukan. Alat peraga yang dibuat sendiri secara langsung oleh siswa akan menambah pemahaman yang lebih baik lagi terhadap pokok bahasan.

\section{SIMPULAN DAN SARAN}

Berdasarkan hasil uji pengolahan data dengan uji-t dan temuan dalam penelitian dapat disimpulkan bahwa ada pengaruh model pembelajaran kooperatif tipe TGT terhadap hasil belajar matematika aspek kognitif dan psikomotor. Hal ini ditunjukkan dengan hasil evaluasi dan unjuk kerja siswa yang lebih baik antara kelas kontrol dan kelas eksperimen. Hasil belajar aspek afektif, hasil antara angket kelas kontrol dan kelas eksperimen tidak terdapat perbedaan. Sehingga dapat disimpulkan bahwa tidak terdapat pengaruh model pembelajaran kooperatif tipe TGT terhadap hasil belajar matematika aspek afektif.

Saran dalam penelitian ini adalah model pembelajaran kooperatif tipe TGT dapat dijadikan alternatif dalam pemilihan model pembelajaran yang memudahkan siswa dalam belajar matematika karena sudah terbukti meningkatkan hasil belajar siswa. Guru hendaknya mengaitkan materi pelajaran dengan masalah yang relevan dalam kehidupan sehari-hari siswa secara nyata. Dalam proses pembelajaran guru sebaiknya menggunakan alat peraga untuk mempermudah siswa dalam pemahaman materi pelajaran. Model pembelajaran kooperatif tipe TGT memang membutuhkan waktu yang relatif lama dalam proses pembelajaran sehingga guru harus bisa memanfaatkan waktu yang tersedia terkait dengan materi yang diajarkan. Rencana tindak lanjut dari penelitian ini adalah mempublikasikan kepada khalayak bahwa bahwa terdapat pengaruh model pembelajaran kooperatif tipe TGT terhadap hasil belajar matematika aspek kognitif dan psikomotor.

\section{DAFTAR PUSTAKA}

Kemendiknas. (2010). Bahan Belajar Mandiri Penilaian Hasil Belajar. Jakarta:Kemendiknas.

Sugiyono. (2010). Metode Penelitian Pendidikan Pendekatan Kuantitatif, Kualitatif, dan $R \& D$. Bandung: Alfabeta.

Sukardi. (2011). Metodologi Penelitian Pendidikan Kompetensi dan Praktiknya. Jakarta: PT Bumi Aksara.

Slavin R.E. (2011). Cooperative Learning Teori, Riset dan Praktik. Bandung: Nusa Media. 